\title{
Pots, Piracy and Aegila. Hellenistic Ceramics from an Intensive Survey of Antikythera, Greece
}

\author{
A. Johnston, A. Quercia, A. Tsaravopoulos, A. Bevan and J. Conolly ${ }^{1}$
}

Postprint of a 2012 paper published in the Annual of the British School at Athens 107.

\begin{abstract}
The small Greek island of Antikythera has a long history of human exploitation, of which one of the most interesting episodes is represented by a fortified settlement on the north coast of the island that can be plausibly identified as a centre of Hellenistic piratical activity. Hellenistic 'Aegila' has left both impressive standing remains and a range of portable finds that have attracted academic interest for over much of the last two centuries. This paper examines the pottery assemblage from this period recovered during a recent intensive survey over the island's entire extent. We consider the spatial and typological character of this material as well as the implications it has for the Hellenistic community's wider social, economic and political connections.
\end{abstract}

\section{Introduction}

In this paper, we offer an overview of the post-Bronze Age and pre-Roman pottery deriving from an intensive survey of the Greek island of Antikythera, Hellenistic and Roman 'Aegila'2, with particular attention to ceramic finds from a nucleated settlement of the Hellenistic period. Antikythera is one of the smallest (20.8 sq.km, maximum elevation $379 \mathrm{~m}$ ) and most physically remote inhabited islands in the Mediterranean, but also lies along major shipping lanes, between the Peloponnese and Crete and between the Adriatic and Aegean seas. Its history of human exploitation begins some 7,000 years ago, but is very patchy, with periods of clear occupation followed by others of near or total abandonment. Perhaps the most well-known archaeological discovery associated with the island is a 1st century BC shipwreck off the north coast that produced the socalled Antikythera mechanism (an intricately-geared astronomical device) as well as an impressive range of bronze statues, ceramic and glass finds (most recently Freeth et al. 2006, with further references). Of course, the contents of this unfortunate passing ship, whilst confirming the island's location in the middle of a risky maritime thoroughfare, says little about the communities living on Antikythera itself. However, there have also been important finds from a limited number of terrestrial investigations, beginning in the latter half of the $19^{\text {th }}$ century (e.g. Zervos-Iakovatos 1972; see also Tsaravopoulos 2009), and focusing on a fortified settlement on the northern side of the island known locally as the Kastro. In 1880, Valerios Stais discovered a votive inscription and statue of Apollo by the harbour of Xeropotamos immediately south-west of the Kastro (Stais 1889) and suggested it was from a local sanctuary. The same area was much later also briefly investigated by Ioannis Petrocheilos (1987). Since 2003 , both the temple and the settlement have seen a renewed programme of excavation by Aris Tsaravopoulos and colleagues (e.g. Papatsaroucha 2002; Tsaravopoulos 2004-9; Tsaravopoulos 2009): as part of this programme, a shipshed on the north side of the Kastro has also been explored, along with a 
contemporary Hellenistic cemetery to the east (figure 2; also Martis et al. 2006), and several clusters of Late Roman cist graves elsewhere on the island (Pyrrou et al. 2006).

In addition, a complementary picture of human activity on Antikythera has recently been provided by a separate programme of intensive surface survey covering the whole island (the Antikythera Survey Project [ASP]). ${ }^{1}$ ASP has involved input from a broad range of specialists interested in the long-term human ecology of the island, in all periods of its history (e.g. Bevan et al. 2008; Bevan and Conolly 2009). The surface survey itself was one aspect of this research effort and its first stage (the only one to be invoked in this paper) was conducted in 2005- 6 by five-person teams walking across the island in lines $15 \mathrm{~m}$ apart. ASP counted over 65,000 potsherds in this manner and made a permanent collection of about 7,725 'feature' sherds for subsequent study (i.e. all rims, bases, handles and all those with paint, glaze or other decoration). Of these collected finds from first stage survey, about 1,550 are judged as possibly or certainly dating to the Classical to Hellenistic period. This paper offers a detailed assessment and selected catalogue of this sample, ultimately to accompany (i) a less discursive, but comprehensive publication of all ASP datasets in digital form and (ii) a more general monograph of the survey results to be published elsewhere.

\section{$<<$ Insert Figure 1 here $>>$}

The discussion below is broken up into general remarks, particular treatment of the earliest material, a catalogue of selected sherds and finally some concluding discussion. The catalogue uses a single running number sequence throughout, but readers should also take note of the associated field identifiers (in brackets) as these are the ones physically marked on the finds and used in other ASP publications. All measurements are in centimetres.

\section{General Remarks}

The pre-Roman material of the Iron Age gathered during the survey comes almost entirely from the Kastro area and its immediate surroundings, with singular exceptions here and there plotted in FIG 1 and 2. Only two areas beyond the Kastro exhibit sufficient sherds to warrant an interpretation as dedicated activity areas, a scatter of material around a possible fortified Hellenistic tower on the hill opposite the Kastro (1203) and a much small group of amphorae above and immediately to the west of the modern harbour (1202). The corpus is also very different from that encountered in other surveys, as will be seen in the figures, catalogue entries and discussion that follow. Because closely datable (e.g. to century-long spans or less) material is scarcely apparent, the duration, or potentially multiple durations, of occupation are not easily discerned, not least during the transition from late Hellenistic to early Roman, while the question as to whether there was continuous occupation throughout Hellenistic is also difficult to address with the present dataset. 
Roughly 1550 pieces are at least possibly Classical or Hellenistic in date, and of these 1050 are amphorae or probably amphorae, 150 small open pots, 100 cooking pots, 70 larger open or wide-mouthed pots, 30 tile, 8 lamps, 5 lids, 5 pithoi, while 140 are largely unidentifiable as shapes (though 65 of these latter are handles, probably of amphorae). Two general chronological points about this assemblage are worth making immediately: first, the vast majority of the total material is from the broad area around the Kastro, with very little found elsewhere on the island. Second, while only a small percentage can be given a close chronological date, the earliest pieces can be safely placed c.350-300, with one probable heirloom from an earlier period (1), there is no clearly diagnostic material of the period c.250-100, while that from the first century consists largely of amphora fragments that cannot be closely dated within the period 100BC-10AD.

Turning to the overall functional character of the assemblage, it is first worth noting that about 1,100 amphora sherds were judged to have been either surely or probably of Classical or Hellenistic date. Overall, 810 of these are handles, 175 rims, 95 toes and 20 body sherds with diagnostic slip, carination, etc). Of this total set of amphorae possibly dating to this broad phase, 485 can be assigned to the Classical-Hellenistic period, and most likely just Hellenistic date, with greater confidence, of which 425 are handles. 45 rims are generically of "mushroom" shape; many are of the more drooping, or very drooping, type (Lawall 2004a, 450-3), indicating a later or considerably later date than the fourth century. A similar number of such rims (ca.40) have been documented by survey on the neighbouring island of Kythera (Johnston, work in progress; the Kythera Island Project), but from 3,500 amphora sherds of Classical-Hellenistic date; most are of earlier types, though we note some later pieces below in footnote 4 .

Compared with other surveyed areas around the Mediterranean with material of the same period, the most striking difference lies in the imbalance of tile against amphora, the former remarkably low, the latter exceptionally high. Clearly, the two patterns need not necessarily be linked, and different social and economic factors are likely to be behind each of them. With regard to amphorae, a good range of possible explanations are available, but perhaps rather fewer with respect to roofing. While the general character of the few tiles found is unremarkable, the white paint on $\mathbf{8 8}$ does stand out, suggesting it does indeed come from the temple which was located close by. It can also be added that there are two local stone fragments of tile from the Kastro (4300-15-1-45-01 and $4318-27-1-35-01$ ), which are clear imitations of ceramic types, with a chamfered edge, and possibly Hellenistic. A plausible explanation for the discarded amphorae is that they are indicative of a passing trade in shipping wine and other goods, while lack of tiles could indicate much reed and mud roofing, especially if we consider roofing practice in recent centuries, or, less likely, removal of tiles by inhabitants emigrating from the island. ${ }^{3}$

A generally recognised difficulty in dealing with pottery of the late Classical and Hellenistic periods in the Aegean is the increasing conformity of shapes and techniques, along with a certain conservatism that, in combination, make it 
difficult to discern local production or stylistic preferences. The island of Antikythera lies between two centres of local power in the period concerned, Sparta and Crete, together with their respective allies. It should be stressed here that Kythera, to the north, has produced very little archaeological material belonging to the main period of habitation on Antikythera. This vacuum would be conveniently explained by a historical model proposing that Cretan groups from the south, perhaps from Phalasarna as the evidence from the Kastro excavations very strongly suggest, drove out the inhabitants of Kythera, while a small sailors' sanctuary on the islet of Mikri Dragonara off Kythera flourished either as a temporary stopover rather than as an indication of local prosperity (Papatsaroucha 2002; Tsaravopoulos 2004-9). However, the Antikytheran survey material does not fully support this notion of exclusively Cretan involvement despite the aforementioned difficulties of regional ceramic identification. For example, Laconian Hellenistic pottery is scantily known, while Cretan has been more fully excavated and published. Yet despite this imbalance in research, the amount of survey material of clearly Cretan origin from Antikythera is slight, while there are rather more pieces of probably Laconian origin, especially in the earliest period of reoccupation, with due notice of the fact that distinctions are more difficult to make in the later material. Fine pottery of the two broad areas uses similar clays and the main small drinking shapes - kantharos, skyphos and echinus bowl - are panhellenic in character. One of our fragments (7) is from a large Cretan cylinder cup or small oenochoe, a hydria rim is probably Cretan (8) and at least a dozen amphorae are of Cretan types or clay, though uncertain date. Of the ten or so pieces more clearly Laconian (all black-glazed) most could still be of the fourth century; they are largely small open vessels, but there is a lamp and a probable jug (the latter a handle fragment not catalogued here).

Some 135 pieces can be loosely called black-glaze, although the term covers a range of finishes, from dull, dark slip (on a few tiles) to a fine gloss finish. While, as noted, ten can be confidently taken as Laconian, only one seems clearly Attic, and most are impossible to assign any further regional provenance. With respect to shape, nearly 100 can only be termed smaller open pots, while ten are too worn to judge whether they are open or closed; the remaining 28 are spread thinly: tile and lamp (6 each), lekane and generic large closed vases (4 each), cooking pot and generic large open vases ( 2 each) and lid, krater, amphora and unguentarium (1 each).

The painted small open pots mainly comprise generic bowls, and especially their ring feet, which amount to some 34 in all, only nine of which can be given to more specific shapes ( 3 fishplates, 2 plates, 1 each: pyxis, salt-cellar, kantharos and skyphos). By contrast, kantharoi feature heavily among handles and body sherds, largely because they are more diagnostic in this respect, while echinus bowls (3) are also identified by body sherds. 15 rims break down into 6 kantharoi, 5 plain vertical (one of which thickened and flat-topped), 2 echinus bowls and 2 ledge rims. A few elaborate feet and body sherds are catalogued below. 
This suite, apart from a few of these last peculiarities, is typical enough of the range of Hellenistic black-glaze overall, and in particular of the earlier part of the period; we should note the lack of more specifically Cretan types (Tulip cup, Cretan kantharos and the like).

\subsection{Possible Earlier Material (i.e. prior to the later $4^{\text {th }}$ century BC)}

Neither survey nor excavation has yet uncovered any evidence for activity on the island after the Third Palace Period in the Bronze Age and prior to the late Classical period (see Pentedeka et al. 2010). While some uncertainty about this absence must remain in the light of our partial knowledge of regional coarsewares (and hence identification via survey) over this timeframe, the overall pattern does suggest the wholesale cessation of permanent settlement. The bulk of the evidence for a subsequent recolonisation is firmly late $4^{\text {th }}$ century $\mathrm{BC}$ as we shall see below, but it is first worth noting that the overall assemblage also provides some very limited evidence for "pre-Macedonian" material, with all due respect to the problems associated with dating ceramic material within the approximate period 350-320 (Rotroff 2007, 810). Among the pieces that contribute to this conclusion, one seems to be an isolated example, while others must hover more generically in a "fourth century, not late" category, given the current state of our knowledge. ${ }^{4}$ The exception is a fragment of a foot of an Attic large vase, krater or hydria, 1, which it would be difficult to place as late as the fourth century and is probably earlier than this. Other feet which would be better placed earlier rather than later in the fourth century are that of a mortar, $\mathbf{2}$, and the disc bases of two Laconian small pots, $\mathbf{3}$ and 4. 5 is a salt-cellar or pyxis perhaps no later than 350 , and one body sherd, $\mathbf{6}$, has very fine black glaze. Some ring foot fragments of smaller open vases (25, 27-8) have a grooved resting surface and could be pre-Hellenistic, though an early Hellenistic date cannot be ruled out (Rotroff 1997, 11). A few other amphora fragments also seem relatively early, though they are not as diagnostic. While there are no mushroom rim fragments of the type with flat top, generically indicative of a fourth century date, some feet could be so placed, for example 76.

The find of a much worn bronze coin of Philip II [FIG 9] on the Kastro also does a little to support an early date for the (re-)settlement, but clearly cannot be pressed as evidence; flan size and thickness merely suggest an earlier rather than later date, while the types are not easily paralleled. We may merely speculate who in the area may have been using such a coin, rare in places so far south, or whether it was brought there casually or not. One possibility of course is that it relates to mercenary pay from one side or other of a conflict, although with only one such piece, it remains impossible to do more than speculate. ${ }^{6}$

In sum, the material evidence from the survey is largely consistent with a foundation of the stronghold c.325 BC. Tsaravopoulos (2004-9) has argued that it was an anti-Macedonian measure taken under the financial support of the Persian king with strong support from Cretan cities, especially Phalasarna. The evidence for this from epigraphic and literary sources is strong, and in general terms can be accepted. There a strong possibility that there was occasional use of the site a little earlier, seen especially in pottery of Laconian origin. The 
limited evidence would suggest that $\mathbf{1}$ is an heirloom, whatever the precise dating of the other pieces in this category.

1 (4307-28-1-25-10) 707230E, 3973912N

Pedestal base of larger Attic vase, krater or hydria. Df c.13. Black glazed outside, reserved under. Date: 7 450-400 BC? [FIG. 3]

2 (4298-20-1-35-2) 707194E, 3973964N

Base fragment of mortar. Df c.20. Burnt. Dark grits on floor. Two grooves on underside. Its condition does not allow accurate estimation of origin, but the general type is close to material from Kythera of the Classical period. Date: $5^{\text {th }}-4^{\text {th }}$ century BC. [FIG. 3]

3 (2008-13-1-65-1) 707440E, 3973455N

Base fragment of open vase, probably cup. Df 4.7. Traces of paint on underside and inside. Laconian. Open vases with disc feet are not surely attested, at least in published material, in Laconia in the Hellenistic period, though the fabric of this piece is not typically classical. Date $4^{\text {th }}-3^{\text {rd }}$ century BC? [FIG. 3]

4 (4314-20-1-25-4) 707263E, 3974027N

Disc foot of a small pot. Df 3. Inside worn; outside black-glazed. Laconian. Fabric seems earlier rather than later, though such bases do appear on small closed pots, which this piece could perhaps be, in the Hellenistic period; see Cavanagh 1996 fig. 15/4, 1, 4 and 5.

5 (4299-15-1-15-1) 707229E, 3973994N

Base and wall of a salt-cellar or pyxis. Df c. 7.5. Wholly black-glazed. The fabric is not Attic, perhaps Laconian. The profile would allow the possibility of this being a skyphos, except perhaps for the very flat underside. The form of ring foot is perhaps more at home in the fifth century, but the relatively thin inner wall might take this piece into the late Classical period or after; see Sparkes and Talcott 1970, 136-7. [FIG. 3]

6 (4328-27-1-5-2) 707342E, 3973991N

Body fragment of a small cup with good black glaze on interior and exterior. MPD 1.8. Probably Laconian. Classical.

\subsection{A Selection of the Later Material (late $4^{\text {th }}$ century to $1^{\text {st }}$ century BC)}

\subsubsection{Fine ware}

7 (4301-17-1-25-1) 707182E, 3974102N

Wall and base fragment of a mug. MPD 5.5. Groove at base of wall, at the turn to a base that is at least in part flat. Perhaps from a Cretan cylinder cup or small olpe. Date: Mid-Hellenistic. [FIG. 3]

8 (4298-20-1-35-7) 707193E, 3973965N 
Rim of hydria? MPD 5.3. Fine buff clay. Substantial diameter. Perhaps Cretan. [FIG. 3]

9 (4330-28-1-45-1) 707341E, 3973847N

Body fragment; curious thick, concave sherd with ribs, most strangely, on the inside. MPD 7.3. Good black glaze in and out. Possibly from a large stand. Date: $4^{\text {th-3rd }}$ century BC. [FIG. 3]

10 (1110-5-1-5-1) 707317E, 3974108N

Foot and body of fish-plate. Df 9.2; MPD 14.5. A large plate, with remains of black glaze inside and out. Rather massive foot and no groove at join of floor and wall. Compare Edwards 1975, 132; akin to Morel 1981, type 1122a but with heavier foot; see also remarks by Rotroff 1997, 146-7, on the variability of detail in Hellenistic plates. Date: Probably later $3^{\text {rd }}$ century BC. [FIG. 3]

11 (4298-28-1-5-9) 707227E, 3973933N

Foot and part of body of fish-plate. Df 8. Rather upright and narrow foot; marked ridge at floor/bowl join. Wholly black-glazed; a band of rouletting on the floor. Date: Probably third century. [FIG. 3]

12 (4314-29-1-45-3) 707284E, 3974051N

MPD 6.2. Lid? Black glaze on interior and exterior; incised groove above rim. [FIG. 3]

Some thirty sherds are from various black-glazed kantharos and cup-kantharos types, though eleven, found at location 1201 (figure 1), belong to probably only three pots (17-19). Five are of cup-kantharoi with a large moulded rib below the rim; another five have vertical fluted or grooved decoration on the body. Two are feet and many of the rest handles. The material is generically of the third century.

13 (4310-28-1-45-11) 707303E, 3973893N

Foot of kantharos. MPD 3.8; Df 6. Wholly glazed. Laconian. [FIG. 4]

14 (4299-28-1-25-2) 707214E, 3974004N

Handle and rim fragment of kantharos. MPD 6.5; Dl 12.3. Wholly glazed. [FIG. 4]

15 (4298-15-1-45-2) 707232E, 3973979N

Wall and handle root of fluted kantharos. MPD 3.3.

16 (4307-26-1-25-3) 707217E, 3973901N

Part of double reed handle of a kantharos. MPD 6.3.

17 (111-g2-2, 111-g2-4 and 111-g2-11) 707104E, 3973363N

Three joining sherds of handle and body of large kantharos or cup-kantharos. [FIG. 4]

18 (111-g2-9) 707106E, 3973363N 
Body fragment of kantharos or cup-kantharos. MPD 1.8. Rouletting on inside.

19 (111-g2-6 and 111-g2-7) 707103E, 3973363N

Two joining fragments of moulded rim of cup-kantharos.

20 (1108-7-1-25-1) 707216E, 3974205N

Moulded rim of cup-kantharos. MPD 3.7.

21 (60-gg1-1) 707957E, 3972137N

Rim fragment of kantharos. MPD 4.2.

22 (5070-1-1-25-1) 708059E, 3973691N

Moulded rim fragment of cup-kantharos. MPD 2.6.

Other black-glazed material ${ }^{6}$

23 (1094-3-1-55-2) 707234E, 3974309N

MPD 7. Foot of bowl. Df 5(only); medium red-brown. [FIG 4]

24 (1061-6-1-55-1) 707127E, 3973374N

MPD 5.5. Grooved ring foot, Df 7, of bowl. [FIG 4]

25 (4298-15-1-35-7) 707233E, 3973969N

MPD 4.4. Slight ledge rim of bowl or cup; Dl c.9. Wholly glazed. Laconian. [FIG. 4]

26 (4299-28-1-15-2) 707215E, 3973997N

MPD 7.2. Bowl; grooved, ring foot, Df7. [FIG 4]

27 (4314-28-1-5-2) 707242E, 3973992N

MPD 7.5. Df 8, vertical ring foot, grooved, with black glaze on interior and exterior. Light pink-red. [FIG 4]

28 (4313-29-1-45-3) 707295E, 3973997N

MPD 5.9. Tall ring foot of bowl, Df 11. Slight groove on stand-ring. One stamped palmette preserved and four rows of degenerate tongue or leaf pattern. Early third century? [FIG 4]

29 (4328-27-1-25-2) 707345E, 3973978N

MPD 8. Df c.13; elaborately profiled, flaring pedestal foot; comparatively thin wall. Large deep bowl. Wholly glazed. [FIG. 4]

30 (4309-15-1-5-6) 707252E, 3973873N

MPD 4.0. Profiled pedestal foot of larger black-glazed vase. Df c.9. Grooved resting surface. [FIG 4]

31 (2010-2-1-55-2) 707469E, 3973323N

MPD 3.2. Rim of echinus bowl, black glazed, Dl c.13. 


\subsubsection{Larger bowls}

32 (4302-29-1-45-1) 707150E, 3974064N

MPD 16.7. Mortar, part of lug handle; ledge rim with groove under edge; Dl 32. Near coarse, buff-brown. [FIG. 5]

33 (4307-29-1-5-1) 707188E, 3973920N

Lekane Dl c.32; MPD 7.2. Ledge rim with horizontal handle under. Near fine medium brown clay.

34 (4299-15-1-25-1) 707226E, 3974011N

MPD 9. Tall concave rim of basin, Dl c.35; buff. [FIG. 5]

35 (4314-20-1-25-1) 707265E, 3974018N

MPD 5.9. Rim of bowl; Dl c.20. Downward sloping rim with handle scar atop. [FIG. 5]

36 (4304-29-1-25-4) 707163E, 3973989N

MPD 5.7. Thickened flat topped rim of large bowl; some traces of black glaze.

37 (4307-28-1-5-6) 707228E, 3973928N

MPD 4.7. Hooked ledge rim of bowl, Dl c.22; buff-brown.

\subsubsection{Lamps and Unguentaria}

Lamps are represented by two black-glazed nozzles, one with rather dull, more brown glaze, 4312-28-1-15.11, another from outside the Kastro, 1062-5-1-85-4, and four bases, three illustrated here [FIG. 5]:

38 (4298-15-1-5-1) 707240E, 3973940N MPD 52; Df 3.3.

39 (4315-35-1-5-3) 707268E, 3974059N MPD 5.2; Df 3.5. Lakonian.

40 (4318-20-1-45-1) 707174E, 3974154N

MPD 5.2; Df 4.1. Underside reserved.

41 (3157-10-1-45-1) 706135E, 3973311N

Df 3.6; generically is of the same general type as the above.

42 (4304-20-1-5-3) 707226E, 3973933N

Foot of an unguentarium. Df 1.8; MPD 3.0. The only such piece found in the survey. There is a splash of glaze on the wall and very slight grooving around the lowest wall. [FIG 5]

\subsubsection{Cooking Pots}


Cooking pots are known from perhaps 50 fragments, but dating is not easy; approximately 35 are handle fragments only and two knobs of lids. Cylindrical handle fragments come from tracts 1062, 1064 and 1094, and a body fragment with part of the ledge from a casserole from 1104.

43 (3010-3-1-35-3) 705999E, 3973854N

MPD 3.1. Folded rim, H 0.8; handle scar below rim. Purple-brown.

44 (4301-17-1-25-3) 707183E, 3974096N

MPD 5.1. Chytra rim, ledge and wall; red-brown, with mica; dark paint on interior. [FIG. 5 ]

45 (4304-29-1-25-9) 707163E, 3973986N

MPD 5.2. Rim and handle root of shallow dish, lopas; bifurcated rim. Grey exterior. [FIG..5]

46 (4302-17-1-15-2) 707125E, 3974074N

MPD 4. Burnt, rim of plain, shallow bowl; coarse, if thin, ware. Fragments of round cooking-pot handles were collected in the same pass.

47 (4319-35-1-45-1) 707150E, 3974213N

MPD 2.7. Slightly concave, vertical rim, $\mathrm{H} \mathrm{1.5;} \mathrm{micaceous} \mathrm{and} \mathrm{other} \mathrm{small}$ inclusions. Probably from a cooking-pot.

48 (4307-20-1-15-3) 707201E, 3973913N

MPD 3. Rim, ledge and handle root of chytra. Orange with grey core.

49 (4298-28-1-25-21) 707222E, 3973954N

MPD 4.7 . Lower rim, ledge and part of high rising handle of a chytra. Redbrown surface; highly micaceous.

\subsubsection{Amphorae}

We illustrate the one stamp and then a range of rims and feet, more to express the diversity of finds rather than suggest provenances. Quercia et al. 2011 have already indicated the range of material belonging to the last two centuries B.C. or slightly later, and ten of the entries catalogued there come from the Kastro. However, it is worth stressing that the majority of clearly Roman pottery comes from other locations on the island in contrast to the very small percentage of Classical to Hellenistic pieces from beyond this zone. Here we merely give skeleton entries for four pieces from the Kastro for which Quercia et al. give a probably Hellenistic date (54-57, the corresponding catalogue numbers in Quercia et al are prefaced ' $Q$ ' J, and note that Q60-64 may belong to the earlier imperial period, with Q71 substantially later. It is not possible to insist on desertion of the site in the mid first century BC from this evidence alone, but when compared with the paucity of fine wares of the period c.100 BC to $50 \mathrm{AD}$ (Q1-3 at most) the case becomes compelling.

50 (4307-20-1-5-3) 707200E, 3973925N 
Stamped handle. MPD 8.1; $2.8 \times 1.9$, near handle join; orange-brown clay with mixed inclusions. The stamp is circular, diam. 1.6, and consists of a ligature not easily interpreted; HPAK would be a possibility, but the alpha is uncertain since there is no sign of an extension of the right leg; beta seems to be present. Very similar is the square stamp from Alexandria, Sztetyłło 1992, 177, no. 53. Not so close is one of the set of Chian stamps from Delos (Grace and SavvatianouPetropoulakou 1970, 358, E233); the clay and handle profile of our piece are similar. The 'syntax' of the ligature is also close to the Boethos stamp on jars from Rhodes or its Peraia of the middle of the third century (Şenol and Doğer 2004, 359). Date: c.250-100 BC (probably Chian) [FIG 5]]

\section{$\mathbf{5 1}$ (4303-17-1-45-1) 707135E, 3974018N}

Light brown clay with phyllite inclusions. Low folded lip; rather rhomboid handle. MPD 10.2; Hl 1.4; handle $3.7 \times 2.4$. The clay could tentatively be taken as Cretan. The existence of Cretan amphorae in the Hellenistic period is problematic. Vogeikoff-Brogan and Apostolakou 2004 have presented some candidates from the east of the island, but Marangou (forthcoming) argues for a lower date for some. Large-scale production appears only at the end of the period, making the pieces catalogued by Quercia et al. from the Kastro (2011: cats.60-64) most probably 'post-destruction'. [FIG. 6].

\section{2 (4314-29-1-45-1) 707285E, 3974048N}

Red-brown clay with phyllite inclusions. Small angular lip, slightly everted. MPD 7. Handles near to strap shape. Again perhaps Cretan clay. [FIG. 6]

53 (4304-28-1-35-6) 707129E, 3973969N

Medium brown, near fine clay. MPD 6.9; Dl 12. Slight lip. Perhaps Rhodian. [FIG. 6]

54 (4299-29-1-25-1 = Q52, q.v.) 707172E, 3974005N

Late Rhodian amphora, rim. D. $7 \mathrm{~cm}, \mathrm{H} .4 \mathrm{~cm}$. Fine and hard reddish yellow clay. Late 1st century BC to mid 2nd century AD.

55 (4314-20-1-35-1 = Q53, q.v.) 707262E, 3974031N

Late Rhodian amphora, rim. D. $12 \mathrm{~cm}, \mathrm{H} .2 .7 \mathrm{~cm}$. Quite fine and hard reddish yellow clay. Late 1st century BC to the mid 2nd century AD.

56 (4303-20-1-15-13 = Q40, q.v.) 707142E, 3974042N

Amphora, rim; Pascual 1 or Dressel 1B? D. $11 \mathrm{~cm}$, H. $6.8 \mathrm{~cm}$. Rough and hard red clay with frequent black inclusions. From the second half of the 1st century BC to the second half of 1 st century $\mathrm{AD}$, although the majority of dateable finds from north-western Europe tend to be Augustan in date.

57 (4300-28-1-25-4 = Q47, q.v.) 707205E, 3974053N

Cyrenaic amphora, rim. D. $17 \mathrm{~cm}, \mathrm{H} .4 .3 \mathrm{~cm}$. Quite fine and hard "sandwich" clay (the core is red-5YR 7/8, the surfaces are black. Mid 2nd to the end of the 1st century BC-early 1 st century AD. 
Tall folded lip, rather flattened handle. Dl 12.5, handle $4.1 \times 2.2$. Red-brown clay with ample small inclusions. Perhaps Lamboglia 2, first century BC or later. [FIG. 6]

59 (4301-28-1-15-2) 707199E, 3974089N

Rather thin vertical rim. MPD 6.9. Dressel 1C. First century BC. [FIG. 6]

60 (4298-28-1-15-11) 707223E, 3973951N

Flaring mushroom rim, with modelling underneath. MPD 13.9; Dl 18. Near fine orange-brown clay. Probably still fourth century. [FIG. 7]

$61(2010-13-1-5-1) 707516 \mathrm{E}, 3973247 \mathrm{~N}$

Triangular mushroom rim. MPD 5.4; Dl 17. Near coarse, micaeous red-brown clay. From a site a little inland from the Kastro area. [FIG. 7]

62 (4310-20-1-35-7) 707280E, 3973870N

Mushroom rim, rather flat handle and neck tapering downward. MPD 9.2. Pinkbuff clay with many, mixed, inclusions. Related to Solocha 1 jars, of varied provenance (Buzoianu 1999, 205, with bibliography) but the taper is very marked. Fourth to third century? [FIG. 7]

63 (15073-58-1-45-2) 707346E, 3973806N

Mushroom rim and flattened handle. Distinct layering of vari-coloured clay. MPD 11.8; Dl 19; handle 4.5 x 1.9. [FIG. 7]

64 (4312-28-1-15-2) 707273E, 3973907N

Folded vertical rim; slight notch near the top outside. MPD 8.5; Hl. 2.8, Dl.c.17. Fine light brown clay with grey core; black paint remains inside, suggesting this may be from a table amphora. [FIG. 7]

65 (4314-28-1-35-1) 707238E, 3974024N

Unusual slight ledge rim. MPD 10.9; handle $3.9 \times 2.1$; Dl c.14. Orange-red clay with mixed inclusions. [FIG. 8 - without handle profile].

66 (4300-28-1-15-16) 707206E, 3974045N

Folded rim, 1.5 high, Dl. c.16. Medium brown clay. [FIG 8]

67 (4327-27-1-5-1) 707331E, 3974053N

Near fine salmon clay. MPD 9.5; Hl 2.4; Dl 13. Punic amphora rim. [FIG 8]

68 (4309-20-1-5-2) 707209E, 3973873N

Red-brown clay with mixed inclusions. MPD 6.5. Punic amphora rim. [FIG. 8]

69 (4298-17-1-15-4) 707210E, 3973948N

MPD 7.4. Rim of Mana type C1. Third or second century; North African. Empereur and Hesnard 1987, 38-40. Compare Q46 and 47 from sites beyond the Kastro. 
MPD 4.7. Rim of Mana type C1. As 69.

71 (4298-28-1-25-28) 707224E, 3973953N

Button foot, hollowed under; full body. MPD 8.2. Rather grey-brown clay with small mica. Perhaps Knidian. [FIG. 8]

72 (4298-15-1-5-5) 707238E, 3973941N

Small button foot attached to long toe. MPD 5.4; Df 3.7, Hf 1.7; buff brown. Nikandros group? Cf. Lawall 2004b 182. [FIG. 8]

73 (4310-20-1-45-5) 707278E, 3973879N

MPD 6.8.

Hollow button foot, base not preserved. Red-brown clay. Perhaps Cretan, from clay. [FIG. 8]

74 (4325-35-1-35-2) 707139E, 3974120N

MPD. 5.7. Df 5.4. Disc foot with hollow under; solid stem. Near fine medium brown clay. Cretan? [FIG. 8]

75 (111-g2-12) 707104E, 3973362N

MPD 6.5. Deep hollow under; solid stem. Pink-buff clay with mixed inclusions. Found in association with kantharos fragments 18-20. [FIG. 8]

76 (1100-6-1-25-1) 707398E, 3974309N

MPD 6. Collared button base; low floor. Light brown clay with small mica. [FIG. 8]

77 (4330-28-1-45-3) 707340E, 3973854N

MPD 5.5; Df 5.6. Ring foot; large shallow hollow under; solid stem partpreserved. Near fine, red-brown clay. Cretan? [FIG. 9]

78 (4330-28-1-45-5) 707340E, 3973851N

MPD 5.6; Df 5.3. Short stem; shallow depression under. Near fine, red-brown clay. Cretan? [FIG. 9]

79 (4330-28-1-45-6) 707340E, 3973849N

MPD 8.4; Df 5. Large button, shallow hollow under. Orange-red clay, some white inclusions [Fig. 9].

80 (4310-28-1-25-10) 707307E, 3973864N

MPD 8.3. Solid base with rounded ring toe. Buff clay with orange core. [FIG. 9]

81 (4310-20-1-35-11) 707279E, 3973871N

MPD 5.8. Flaring stemmed foot. Light beige clay with mica. [FIG. 9]

82 (4298-28-1-45-7) 707220E, 3973972N

MPD 4.9; Df 5.5; very worn. Solid stem, hollow under. Pink-brown clay, with small mica and other mixed inclusions. [FIG. 9] 
83 (4306-15-1-25-3) 707106E, 3973986N

MPD 5.7; Df 5.5. Flaring low disc foot, broad hollow under. Near coarse clay. [FIG. 9]

84 (4310-26-1-25-2) 707293E, 3973867N

MPD 7; Df 5. Flaring disc foot. Beige clay. [FIG. 9]

85 (4298-17-1-5-7) 707212E, 3973931N

MPD 6.1; Df 6.2. Flaring stem, deep hollow under. Near fine pink-brown clay. [FIG. 9]

\subsubsection{Tiles}

About half the tile fragments, catalogued because they have an edge or some paint preserved, are of the broad Classical to Hellenistic period, some 30 in all, of which $80 \%$ are from the Kastro. Two-thirds of these have a thickened chamfered edge. Six preserve paint, of varying character, on the upper, concave surface; three have straight edges, probably the upper edge in two examples, but one has two adjacent straight edges. Only one seems to be a cover tile. The survey unit, where $\mathbf{6 3}$ was found also yielded a tile, with chamfered edge, 1.9 thick (15073-58-1-45-1; MPD 9.4); the coarse yellow clay could perhaps suggest a more recent date than Hellenistic, despite it being fairly thick. Two other tiles probably and one more certainly represent the period outside the Kastro:

86 (1062-6-1-35-2) 707127E, 3973304N

No edge preserved. MPD 4.8. 1.7 thick. Probable paint remains. A corner fragment from the same site is not closely datable.

87 (3207-19-1-45-1) 706259E, 3973051N

Straight edge. MPD 8.5. 1.4 thick. Near fine orange-buff clay.

88 (1129-3-1-15-1) 707264E, 3973761N

Fragment of an eaves tile, preserving front edge only, which is thickened. Part of the black-glazed top surface is preserved, with a shallow groove near the front. The front surface is worn, but has a white band at the top. The underside is plain, with a light groove near the front. The find comes from the surface of the temple of Apollo, situated near the modern-day beach and at the foot of the Kastro. Lack of lateral curvature does not assist interpretation, but it may be noted that Petrocheilos (1987 38) also noted the presence of a Corinthian tile fragment at this site. If indeed this temple had a Corinthian roof it would be of considerable interest in view of the use, albeit restrained, of Laconian tiles elsewhere on the island. It would point towards Crete as the architectural origin. [FIG. 9]

\section{Commentary}


Material of the Greek period found during the survey is confined very largely to the area of the Kastro and its surrounding zone, in great contrast to the evidence from other periods (e.g. Bevan and Conolly 2009, 962). The vast bulk consists of pottery, notably transport amphorae, though the picture is rounded out, from survey and excavation, by some scatters of metalworking slag in several parts of the town, stone catapult balls, iron and bronze arrowheads, lead sling bullets and coins (FIG 2; Tsaravopoulos 2004-9). Two tiles in stone stand out when compared with the very few clay tiles found in the entire survey.

Chronologically, pottery from the survey of the Kastro area is broadly consistent with a start date in the late part of the $4^{\text {th }}$ century BC and an end date in the $1^{\text {st }}$ century $\mathrm{BC}$, but there is nonetheless at least a hint of slightly earlier material on the island (whether heirlooms or the residue of light visitation), and the end date is also hard to define with absolute confidence, though it should certainly lie somewhere in the $1^{\text {st }}$ century BC. In our publication of the Roman material (Quercia et al. forthcoming) a small number of sherds, mainly of amphorae, could only be generically dated to a period between the $2^{\text {nd }}$ century BC and $1^{\text {st }}$ century AD. From preserved literary sources, notably Plutarch Life of Pompey xxix, we would expect at least a drastic reduction in habitation after 69-67 BC as a result of Metellus' Cretan and 'anti-piracy' campaign, and there is nothing in the archaeological record which forbids such a conclusion. In considering the nature of naval activities conducted from the island, we should certainly heed de Souza's caution on overstating the extent of blatantly piratical activity $(1999,58-9)$, but the near lack of non-maritime resources to support the population of the island does make piracy a more plausible major source of livelihood for the inhabitants, or their masters.

With respect to the earliest dateable material from the period under consideration here, it may be noted that it includes one probable heirloom and several pieces of Laconian ware which prima facie appear to be still of Classical date, though the repertoire of production in Laconia in the later fourth century is very poorly attested. There are fewer hints of Cretan presence in the pottery remains, though they do exist; here again, our current knowledge of Cretan amphora production for most of the Hellenistic period is very limited, and suggestions made in the catalogue above are based more on the clays than on typological aspects. Moving beyond the ceramic record, the probability that Phalasarna and Antikythera were fortified at roughly the same period is suggestive of a political link between the two, although it should be noted that the published material used to date Phalasarna is very limited and not immediately comparable to that from the Kastro (Hadjidaki and Iniotakis 2000, 55; the piece illustrated in their fig. 8 could well be later than the suggested construction date of c.335-30; Sekunda 2004-9). The results from survey on Kythera to the north suggest a drastic if not total reduction in late Classical period occupation in the area surveyed, at roughly the time Antikythera is repopulated. From the ceramic records of the two islands it is difficult to discern the respective participation of Sparta and Cretan cities in opposing Macedonian pressure in the period concerned. 
To conclude, ASP has provided an interesting and often challenging selection of material which can or may date to the Hellenistic period. It will in due course be complemented by more material, some stratified, from the ongoing excavations on the Kastro site. The main picture that emerges is of a site handling a great deal of amphora traffic, concentrated at either end of the Hellenistic period, as far as the record of more closely datable material allows us to judge. A scatter of both storage and fine wares appears on other sites, but most are close (even in Antikytheran comparative terms!) to the Kastro, for example some amphorae, the tile 88 and a lamp (41) from the area to the west of the modern harbour, with 43 from further NW. 22 is from east of the Kastro, not far from a known cemetery area. Nearly all finds probably of the period at any further distance from the Kastro are singletons, perhaps some thirty sherds, largely amphorae of types found at the Kastro; there are some black-glazed pieces, including $\mathbf{2 1}$ from the central part of the island and a body fragment of a small echinus bowl from the southernmost tip. There is a broad representation of ceramic shapes; the lack of large storage vessels need not surprise us in view of the obvious availability of amphorae. Only a small percentage of these jars can be given a firm provenance, but it is clear that they hale from many parts of the Mediterranean (though none obviously from the Pontus, though Heraclean jars are known from the Kastro excavation). How many may be reasonably local remains an unknown factor in view of the dearth of published material from western Crete; certainly the southern Peloponnese is an unlikely source. No double-barrelled Koan or pseudo-Koan handles were collected, which may be a chronological pointer to their production being largely of a date after 75-50 BC, though the excavations of Tsaravopoulos and colleagues on the Kastro have yielded some examples.

Can we discern piratical activity from this record? While the fort was almost certainly founded as some form of civic undertaking, best exemplified by the temple with its probable Cretan roof, it is difficult to discern the character of the activities of its inhabitants throughout the period in question. There is no fertile hinterland, such as led the Cilicians to copy others' amphora types in or after their piratical heyday (Rauh 2004). Brulé (1978, part iii, esp. 156-162) has demonstrated from literary and epigraphic evidence how outlaw maritime activity was a deep-rooted feature of Cretan society from perhaps as early as the fifth century, sometimes blurring the borderline between warfare and piracy. Our pottery assemblage cannot throw light on these matters, though the lack of clearly diagnostic material from the period c.250-150 does raise points of interest. The period coincides with the acme of Cretan privateering; we would expect occupation by Cretans, and some of the lead bullets found on the Kastro may date to the later third century (Tsaravopoulos 2004-9, esp. 334-5). In contrast, the possible pottery lacuna does arguably fit reasonably well with an early to mid-third century date for a Rhodian assault on the island suggested by epigraphic evidence (Segre 1932, 456-61; Martis et al. 2006, 125-6), which may thus have led to a period of abandonment and our possible archaeological blank. We can merely surmise that Cretan groups did retain usage, principally as a refuge (conceivably later to be attacked by Philip V or Nabis, or indeed both), while epigraphic evidence shows their eagerness to dispose of booty, human or otherwise, as speedily as possible, leaving little archaeological trace. Certainly 
the lack of finds beyond the Kastro suggests a period of uncertainty and discontinuity. 


\section{Notes}

1. ASP has been a synergasia between Bevan, Conolly and Tsaravopoulos and they would like to thank the Greek Ministry of Culture, the Greek Archaeological Service (26th EPKA, 1st EBA), as well as our three primary external funding agencies over the duration of the project-the Social Science and Humanities Research Council of Canada, the UK Arts and Humanities Research Council and the Institute for Aegean Prehistory. The Mediterranean Archaeological Trust also contributed to the costs of photographing and illustrating the artefacts included in this paper. Our sponsor in Athens, the Canadian Institute in Greece, particularly Jonathan Tomlinson, was helpful in the coordination of the permit logistics, and we are extremely grateful for its assistance in this regard. Several of us have also been involved in survey work on the neighbouring island of Kythera, with the Kythera Island Project (www.ucl.ac.uk/kip), and we are grateful to Cyprian Broodbank and Evangelia Kiriatzi (KIP co-directors) for advice and support. Denitsa Nenova illustrated the sherds catalogued here, with further assistance by Marek Maciusowicz and James O'Neill. ASP databases and photographs can be downloaded at www.ucl.ac.uk/asp and/or www.tuarc.trentu.ca/asp. They will be archived with the UK Archaeology Data Service (http://ads.ahds.ac.uk/) and are also available from Bevan or Conolly on request. Johnston thanks Elpida Kosmidou for numismatic assistance.

2. Antikythera, as Aegila or Aegilia, is mentioned in a variety of Hellenistic to Roman sources (e.g. Plutarch Cleomenes 31.1- 32.1; Lycophron Alexandra 108; Pliny the Elder Historia Naturalis 4.19; Stephanus of Byzantium Ethnica; see also Jacopi 1932: 169-70).

3. A comparable situation is found at the site on Diakofti island (Kythera Island Project site 137A-B), and we can also note the concentration of activity during the Hellenistic period at the nearby islet of Mikri Dragonera. Johnston is grateful to Simon Price for the advice that tile is a relatively less common find from surveys on Crete than elsewhere, though more frequent overall than we find in the limited periods of occupation on Antikythera. Tsaravopoulos notes that in the modern period tiles were rarely used on the island.

4. Waterhouse and Hope-Simpson 1961 162-3, talk of late fifth century sherds picked up during their visit to the site, but for the earlier period only enter in their catalogue a kantharos foot, probably of the fourth century, but not necessarily the first half, and a shallow bowl, termed a fishplate, of no clear date (1 and 3, fig. 21c-d); unillustrated are two "fifth to fourth century" amphora feet, together with two oenochoe fragments ( 2 and 4 ).

5. It is ironic that Waterhouse and Hope-Simpson (160) note the presence in the museum on Kythera, likely to be of Kytheran provenance, of coins of both Aegina (or Kydonia?) and Philip.

6. The following very worn rims from the Kastro may also be noted:

4309-29-1-5-4. MPD 2.5. Plain vertical rim of bowl, wholly black glazed. 
4307-20-1-45-2. MPD 5.6. Ledge rim of bowl, two grooves on top; buff-brown clay. Glaze fired red-brown.

4307-20-1-35-12. MPD 3.9. Large echinus bowl, very worn, Dl c.14.

7. Note that in the catalogue entries that follow, date ranges are only given where it seems possible to offer narrower ranges than "Hellenistic-Early Roman" or those implied by the two chronological sub-sections of the catalogue (3.1 and 3.2). 


\section{Abbreviations}

MPD maximum preserved dimension

Dl lip diameter

Hl lip height

Df foot diameter

Hf foot height

\section{Bibliography}

Bevan, A. and Conolly, J. 2009. 'Modelling Spatial Heterogeneity and Nonstationarity in Artifact-Rich Landscapes', Journal of Archaeological Science 36.4, 956-964.

Bevan, A., Conolly, J. and Tsaravopoulos, A. 2008. 'The Fragile Communities of Antikythera', Archaeology International 10, 32-36.

Brulé, P. 1978. La piraterie cretoise hellénistique (Paris).

Buzoianu, L. 1999. 'Types d'amphores héllenistiques découvertes à Callatis', in Garla, Y. (ed.), Production et Commerce des Amphores ancienes en Mer Noire (Aixen-Provence), 201-14.

Cavanagh, W.G. 1996. Continuity and change in a Greek rural landscape: the

Eiring, J. and Lund, J. 2004. Eds, Transport Amphorae and Trade in the Eastern Mediterranean (Acts of the International Colloquium at the Danish Institute at Athens, September 26-29, 2002; Aarhus).

de Souza, P. 1999. Piracy in the Graeco-Roman World (Cambridge).

Edwards, G.R. 1975. Corinth vii, 2; Corinthian Hellenistic Pottery (Princeton).

Empereur, J.-Y. and Hesnar, A. 1987. 'Les amphores hellènistiques' in Lèvêque, P. and Morel, J.-P. (eds), Céramiques héllenistiques et romaines ii (Besançon) 9-71.

Freeth, T., Bitsakis, Y., Moussas, X., Seiradakis, J.H., Tselikas, A., Mangou, H., Zafeiropoulou, M., Hadland, R., Cate, D., Ramsay, A., Allen, M., Cawley, A., Hockley, P., Malzbender, T., Gelb, D., Ambrisco, W. and Edmunds, M.G. 2006. 'Decoding the ancient Greek astronomical calculator known as the Antikythera Mechanism', Nature 7119, 587-591.

Grace, V. and Savvatianou-Petropoulakou, M.1970. 'Les timbres amphoriques grecs' in Bruneau, P. (ed.) Délos 26. L'îlot de la maison des comédiens (Paris), 277386.

Hadjidaki, E. and Iniotakis, I. 2000. ' Hellenistic ceramics from Phalasarna found from 1986-1990', The Ancient World 31, 54-73. 
Jacopi, G. 1932. 'Nuove Epigraphi Dalle Sporadi Meridionali', Clara Rhodos 2, 165-256.

Lawall, M. 2004a . 'Amphorae without stamps: chronologies and typologies from the Athenian Agora', in 6th Scientific Meeting on Hellenistic Pottery, Volos, April 2000. Athens.445-54. [NB no editor cited]

Lawall, M. 2004b. 'Archaeological context and Aegean amphora chronologies: a case study of Hellenistic Ephesus', in Eiring and Lund 2004, 171-88.

Marangou, A. forthcoming 'Stamping of Cretan amphorae in the Hellenistic period: a revised chronology', in the Proceedings of the international colloquium 'Analyse et Exploitation des Timbres Amphoriques Grec', Athens 3-5 February 2010.

Martis, T., Zoitopoulos, M. and A. Tsaravopoulos 2006. 'Antikythera. The Early Hellenistic Cemetery of a Pirate's Town', in Luca, S.A. and Sîrbu, V. (eds.), The Society of the Living - the Community of the Dead (from Neolithic to the Christian Era); Proceedings of the 7th International Colloquium on Funerary Archaeology (Sibiu), 125-134.

URL:

http://arheologie.ulbsibiu.ro/publicatii/bibliotheca/acta\%20V\%20special\%20n umber/volum\%20syposion\%20funerary.pdf

Morel, J.-P., 1981. Céramique campanienne: les formes (Rome).

Nørskov, V. 2004. 'Amphorae from three wells at the Maussolleion of Halikarnassos; something to add to the typology of mushroom rims?', in Eiring and Lund 2004, 285-92.

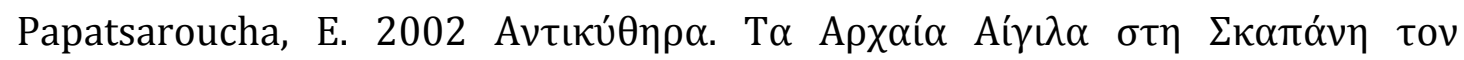

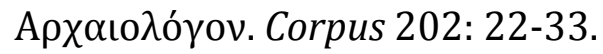

Pentedeka, A., E. Kiriatzi, L. Spencer, A. Bevan, J. Conolly 'From Fabrics to Island Connections: Macroscopic and Microscopic Approaches to the Prehistoric Pottery of Antikythera', Annual of the British School at Athens 105.

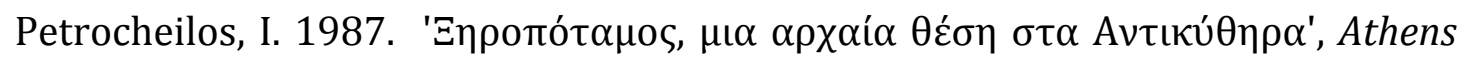
Annals of Archaeology 20, 31-42.

Quercia, A.,. Johnston, A., Bevan, A., Conolly, J. and Tsaravopoulos, A. forthcoming. 'Roman Pottery from an Intensive Survey of Antikythera, Greece', BSA 106.

Rauh, N. 2004. 'Pirated knock-offs: Cilician imitations of internationally traded amphorae' in Eiring and Lund 2004 329-36.

Rotroff, S. 1997. The Athenian Agora xxix, part 1; Hellenistic Pottery. Athenian and Imported Wheelmade Table Ware and Related Material (Princeton). 
Rotroff, S. 2007. Review of S. Drougou, Vergina : ta pēlina angeia tēs megalēs toumbas (Athens 2005) in AJA 111, 809-10

Segre, M. 1932. 'Due nuove testo storici', Riv.Fil. n.s. 10, 446-61.

Sekunda, N. 2004-9. 'The date and circumstances of the constructioin of the forticiations at Phalasarna', Horos 17-21: 595-600.

Şenol, G.C., Şenol, A.K. and Doğer, E. 2004. 'Amphora production in the Rhodian Peraea in the Hellenistic period', in Eiring and Lund 2004, 353-9.

Sparkes, B.A. and Talcott, L. 1970. The Athenian Agora xii; Black and Plain Pottery of the 6th, 5th, and 4th centuries (Princeton).

Sztetyłło, Z. 1992. 'Timbres cèramiques des fouilles polonaises à Alexandrie (1979-1982)', Etudes et travaux 16, 151-178.

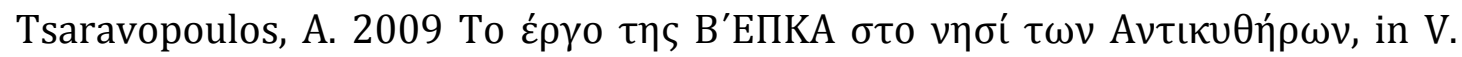
Vasilopoulou, St. Katsarou-Tzeveleki (eds.) From Mesogeia to Argosaronikos, Proceedings of the Conference: B Ephorate of Prehistoric and Classical Antquities, Research of a Decade: 577-592. Markopoulou: Demos Markopoulou Mesogaias.

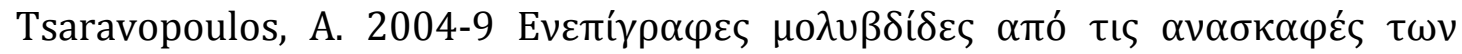

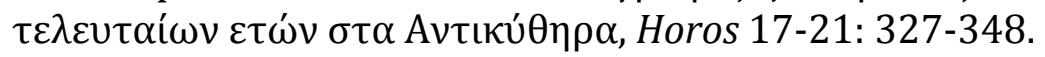

Vogeikoff-Brogan, N. and Apostolakou, S. 2004 'New evidence of wine production in East Crete in the Hellenistic period', in J. Eiring and J. Lund (eds.), Transport Amphorae and Trade in the Eastern Mediterranean (Acts of the International Colloquium at the Danish Institute at Athens, September 26-29, 2002; Aarhus), 417-27.

Waterhouse, H. and Hope-Simpson, R. 1961. 'Prehistoric Laconia: part II', BSA, $56,114-175$.

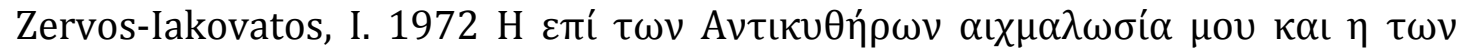

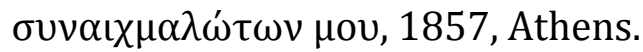




\section{List of Figures}

Figure 1. Maps of Antikythera showing a) the island's general location in the Aegean and the distribution of Classical to Hellenistic (mainly Hellenistic) sherds recovered from systematic survey, and b) the location of denser artefact scatters along with the UTM grid (zone 34N, WGS84) used in the catalogue.

Figure 2. Plan of the Kastro with standing remains, special finds and pottery from stage-one survey shown (the background image dates to February 1944; courtesy of the UK Aerial Reconnaissance Archive)

Figure 3. Line drawings of sherds 1-3, 5, 7-12

Figure 4. Line drawings of sherds 13-14, 17, 23-30,

Figure 5. Line drawings of sherds 32-4, 35, 50, 38-41, 44-45, 50

Figure 6. Line drawings of sherds 51-53, 58-59

Figure 7. Line drawings of sherds 61-64

Figure 8. Line drawings of sherds 65-68, 71-76

Figure 9. Line drawings of sherds 77-85, 88 and coin 


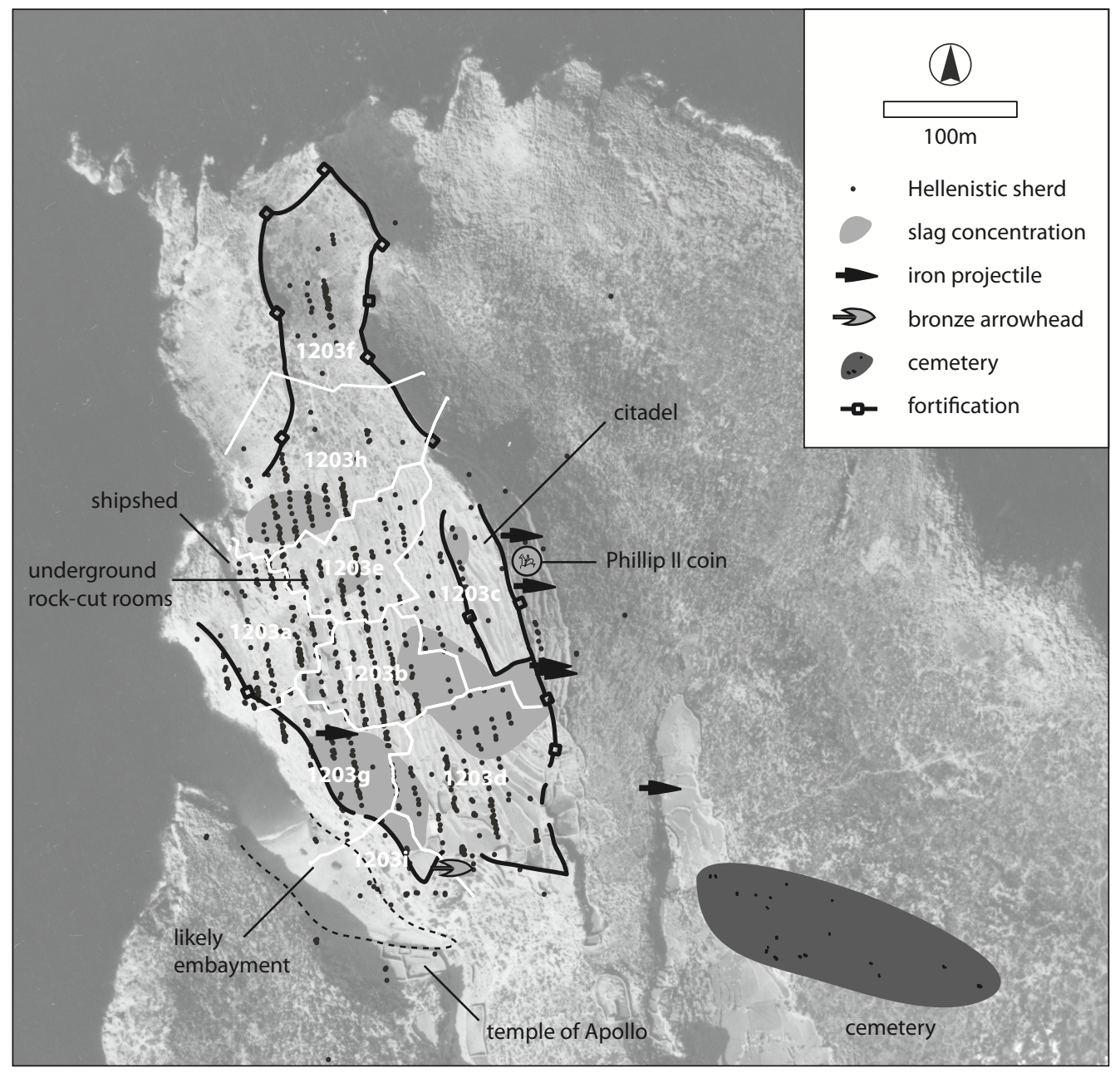




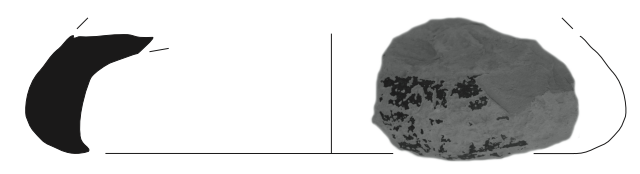

1 (4307-28-1-35-10)

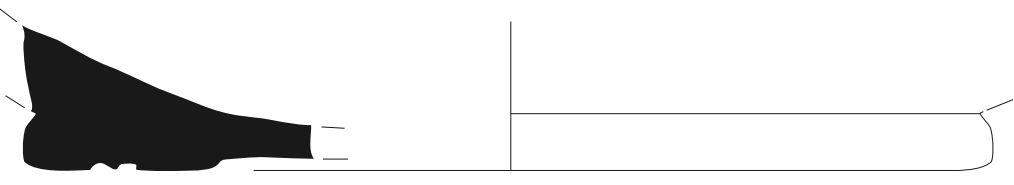

2 (4298-20-1-35-2)

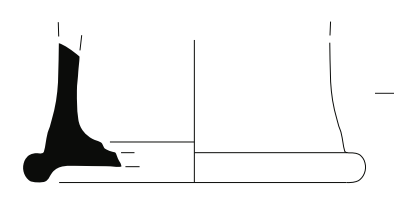

5 (4299-15-1-15-1)

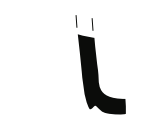

7 (4301-17-1-25-1)

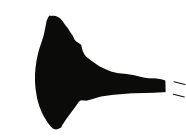

8 (4298-20-1-35-7)
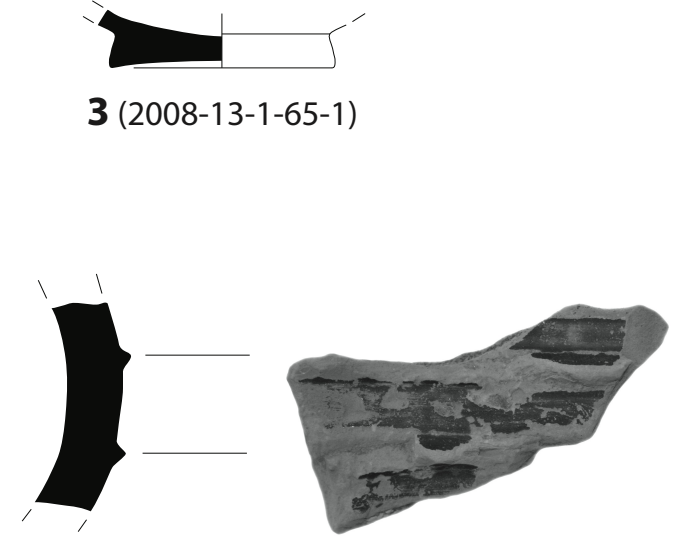

9 (4330-28-1-45-1)

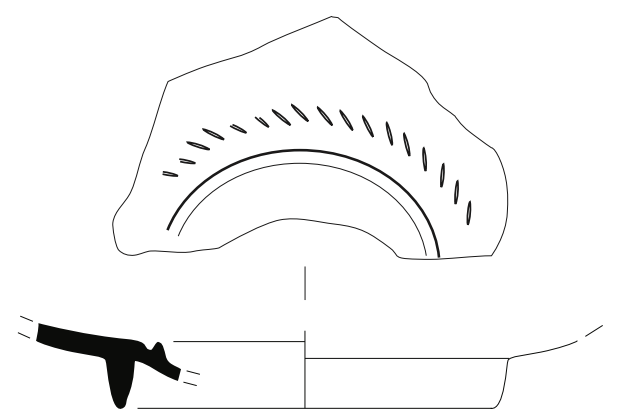

11 (4298-28-1-5-9)

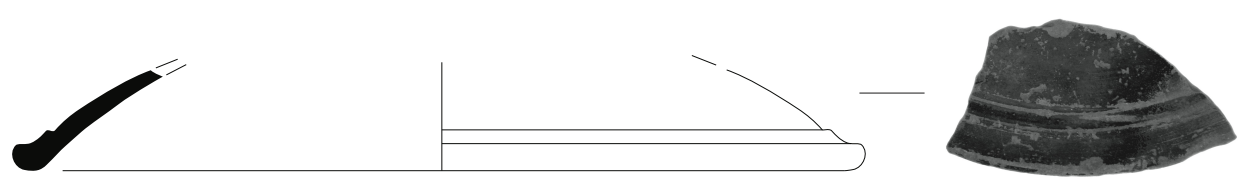

12 (4314-29-1-45-3) 


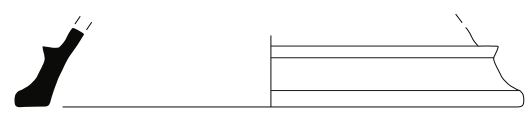

13 (4310-28-1-45-11)

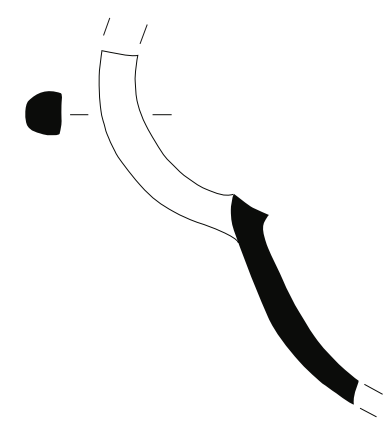

17 (111-G2-2-4-11)

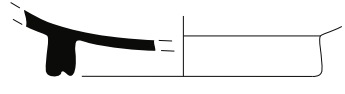

23 (1094-3-1-55-2)

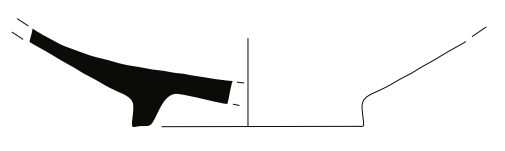

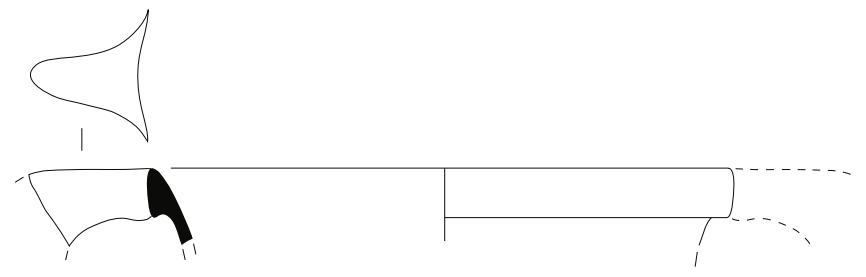

14 (4299-28-1-25-2)

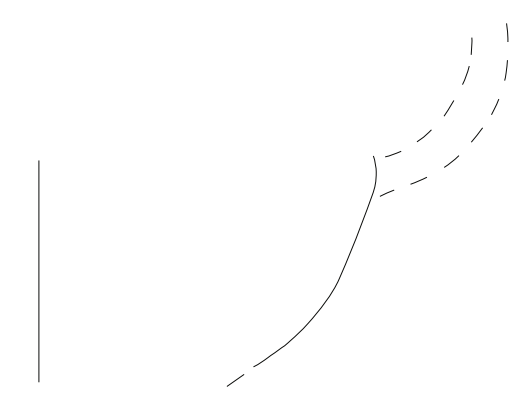

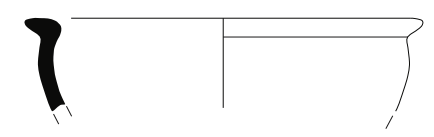

25 (4298-15-1-35-7)

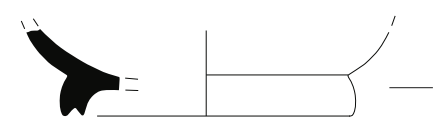

26 (4299-28-1-15-2)

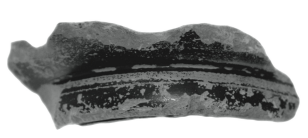



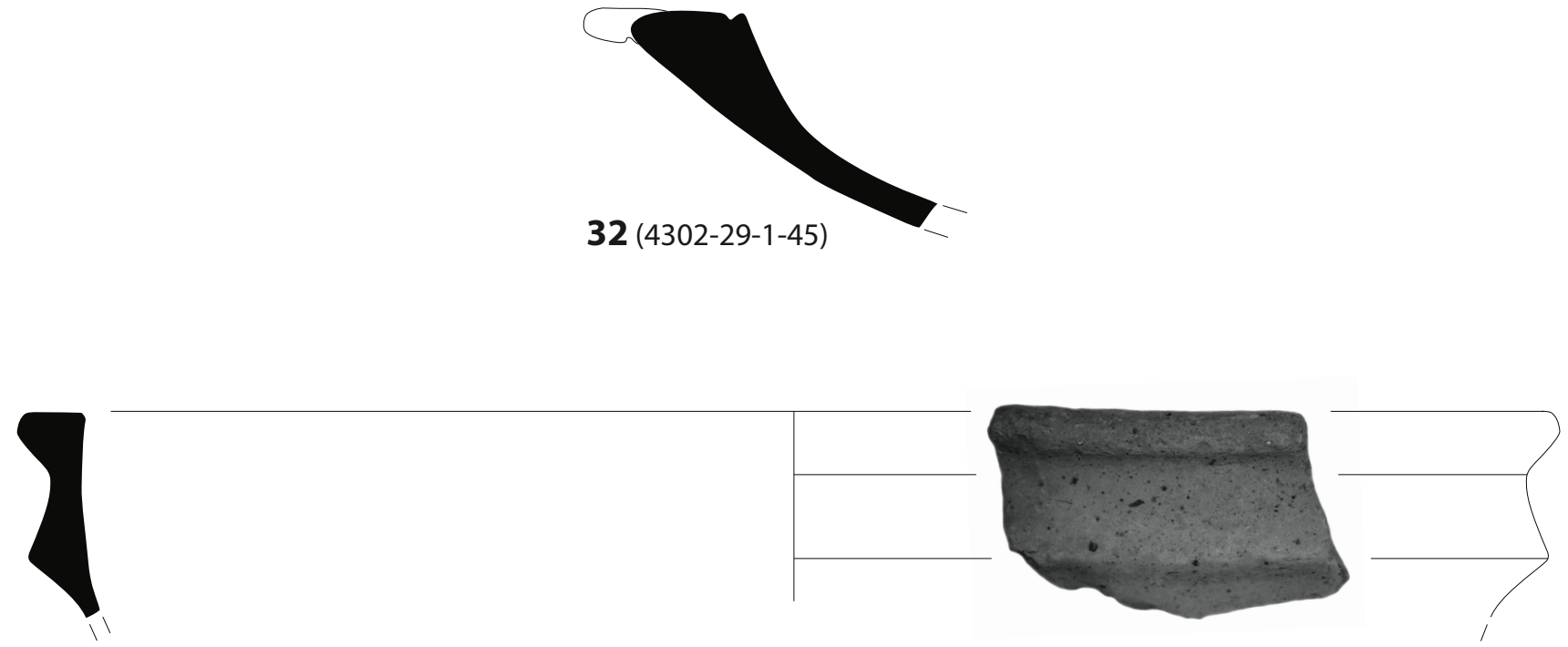

34 (4299-15-1-25-1)

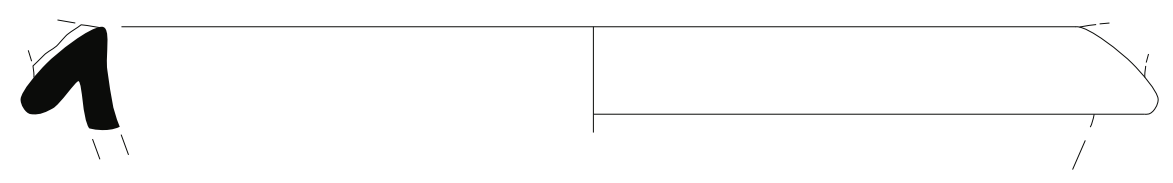

35 (4314-20-1-25-1)

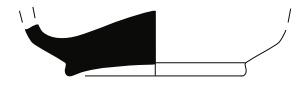

38 (4298-15-1-5-1)

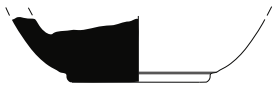

39 (4315-35-1-5-3)

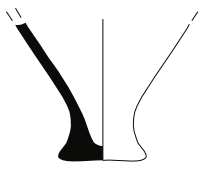

41 (4307-28-1-58)

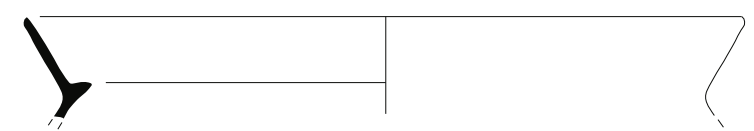

44 (4301-19-1-25-3)

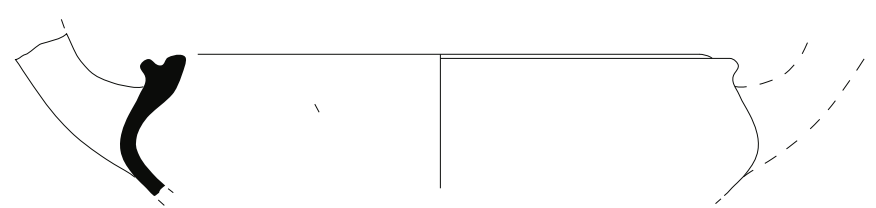

45 (4304-29-1-25-9)

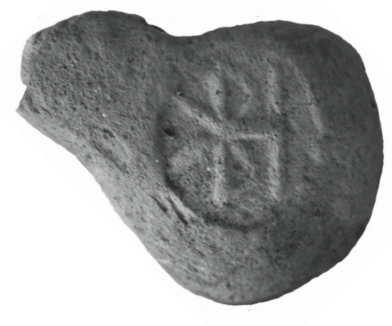

50 (4307-20-1-5-3) 

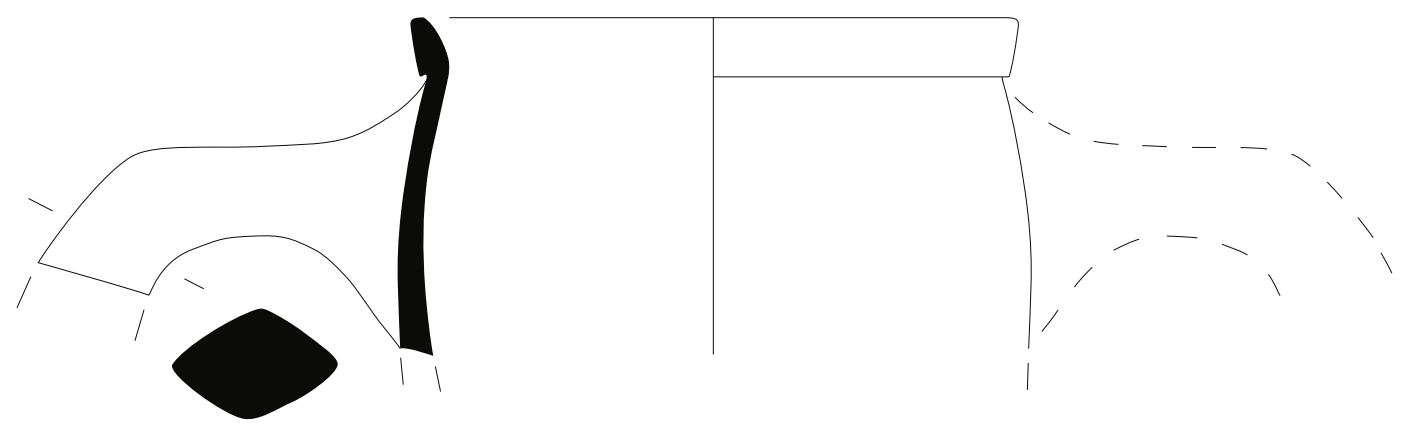

51 (4303-17-1-45-1)

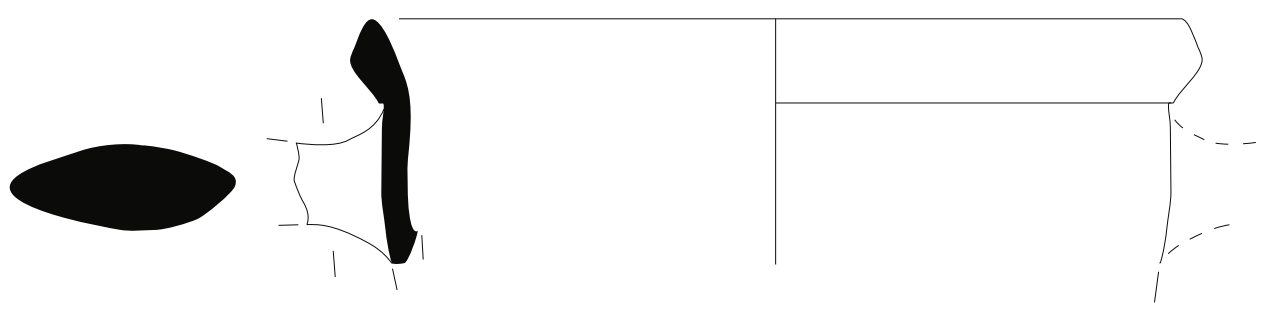

52 (4314-29-1-45-1)

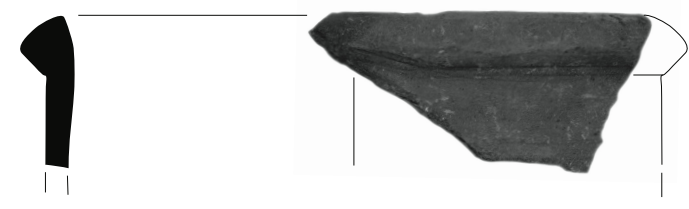

53 (4304-28-1-35-6)

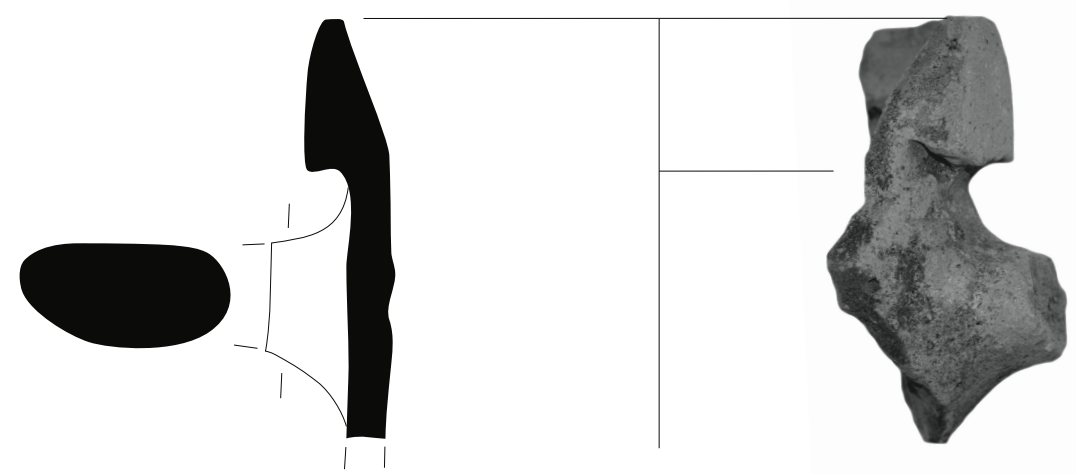

58 (5044-2-1-15-2)

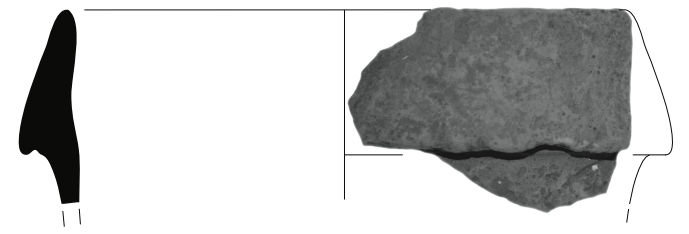

59 (4301-28-1-15-2) 


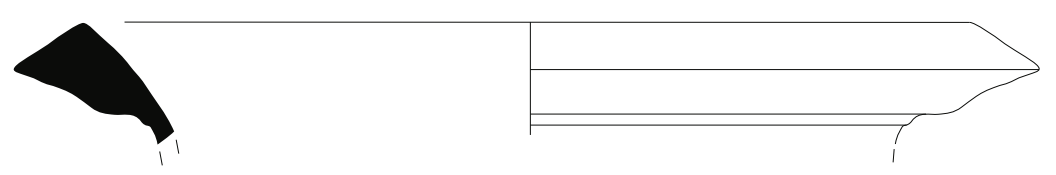

60 (4298-28-1-15-11)
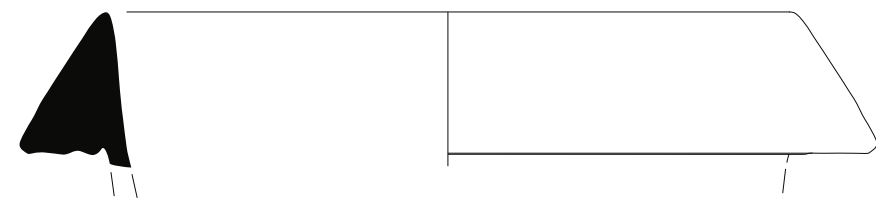

61 (2010-13-1-5-1)

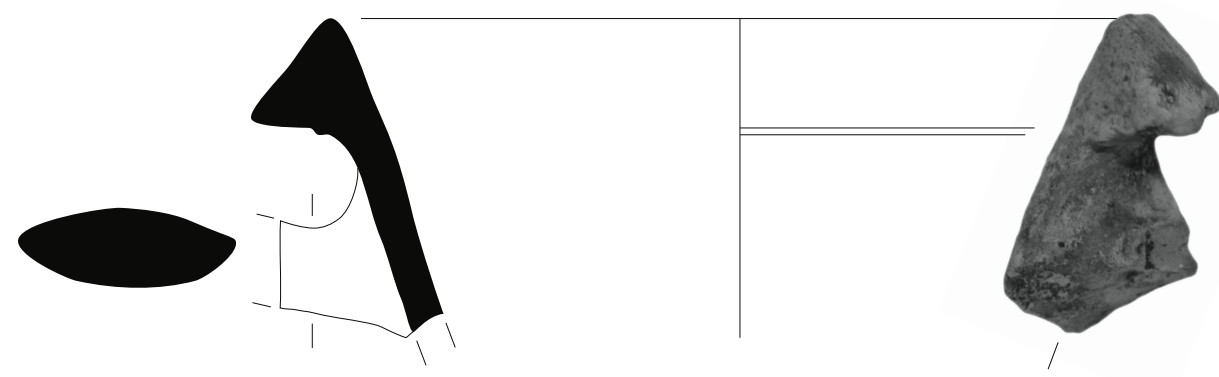

62 (4310-20-1-35-7)

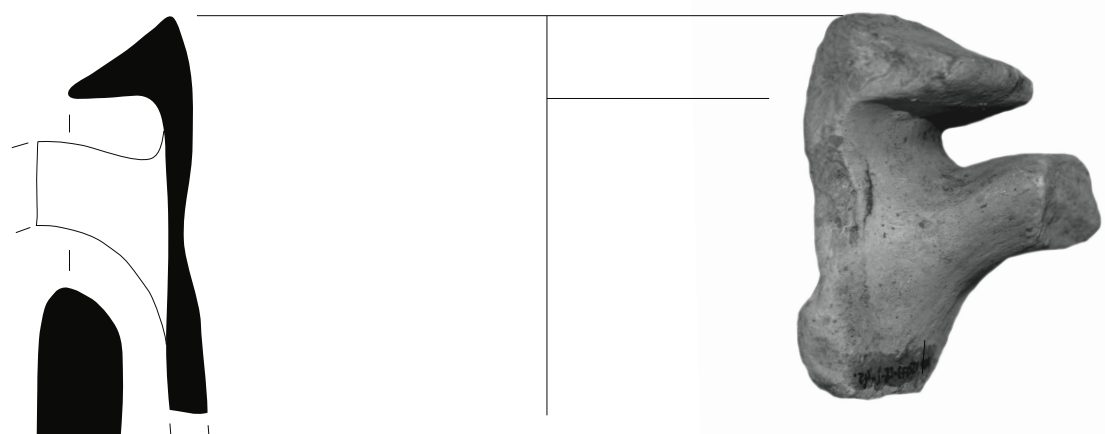

63 (15073-58-1-45-2)

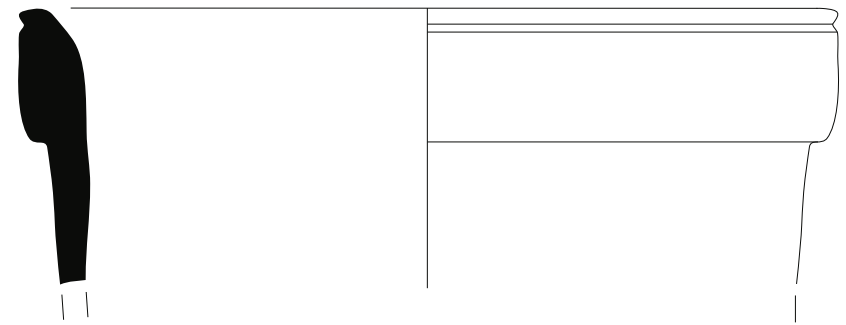

64 (4312-28-1-15-2)

0 $5 \mathrm{~cm}$ 

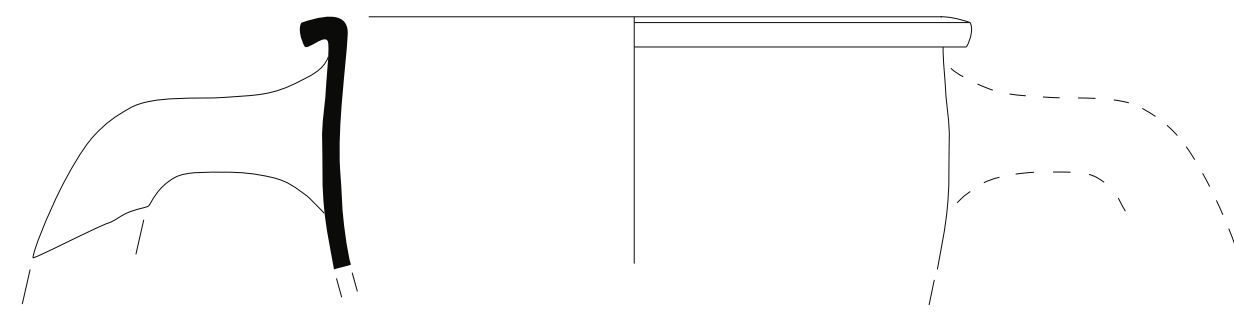

65 (4314-28-1-35-1)

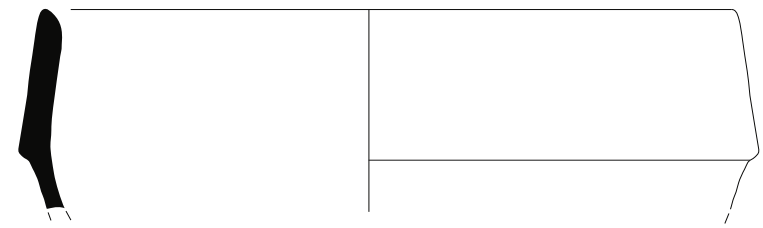

66 (4300-28-1-15-16)

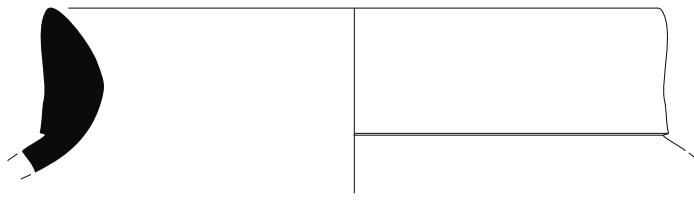

67 (4327-27-1-5-1)

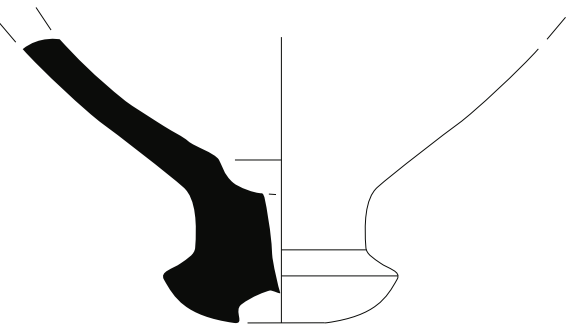

71 (4298-28-1-25-28)

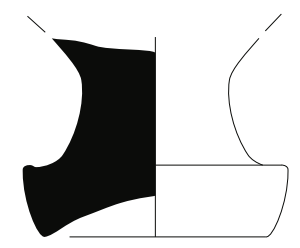

74 (4325-35-1-35-2)

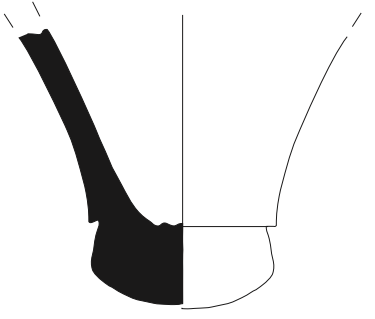

72 (4298-15-1-5-5)

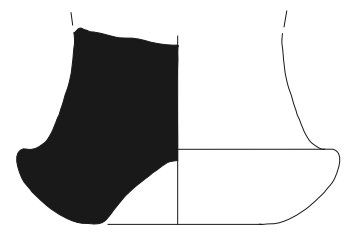

75 (111-g2-12)

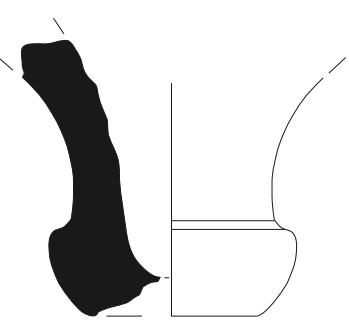

73 (4310-20-1-45-5)

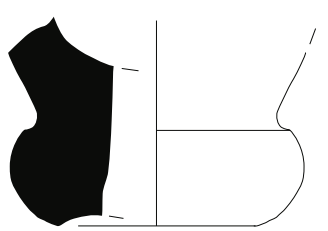

76 (1110-6-1-25-1) 


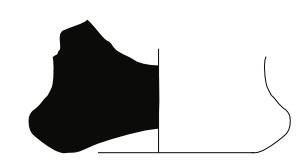

77 (4330-28-1-45-3)

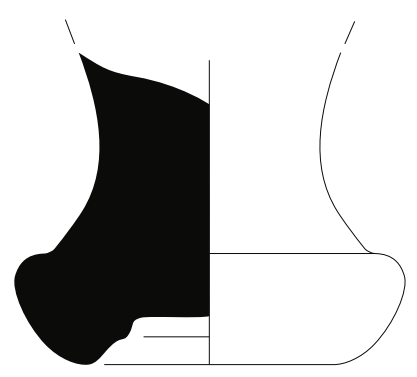

80 (4310-28-1-25-10)

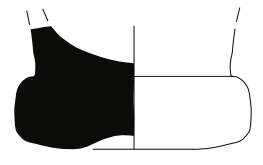

78 (4330-28-1-45-5)

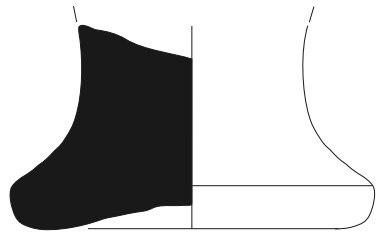

81 (4310-20-1-35-11)

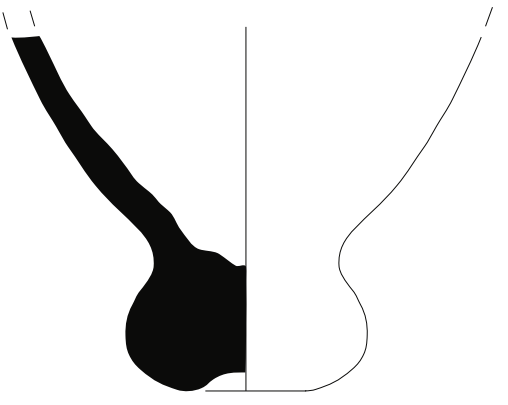

79 (4330-28-1-45-6)

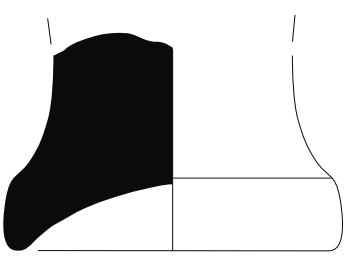

82 (4298-28-1-45-7)

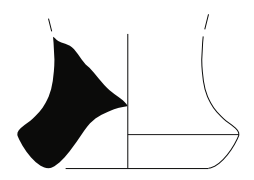

83 (4306-15-1-25-3)

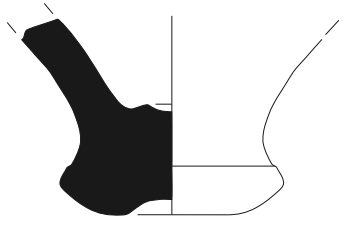

84 (4310-26-1-25-2)

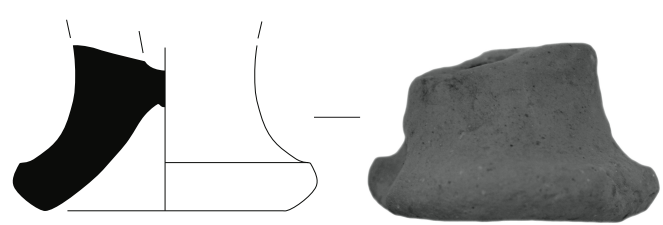

85 (4298-17-1-5-7)

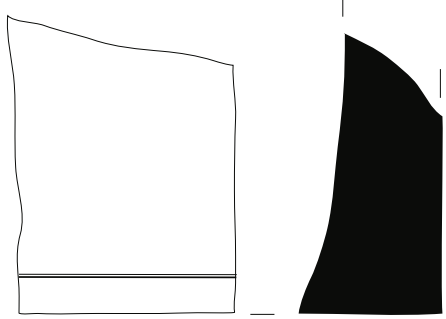

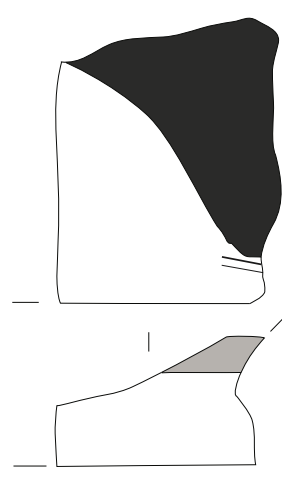

88 (1129-3-1-15-1)

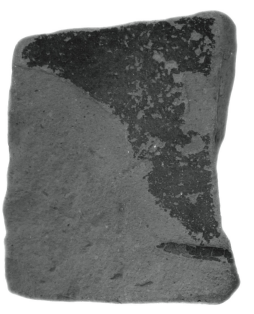
(at $2 x$ the stated scale) 20-g2-01

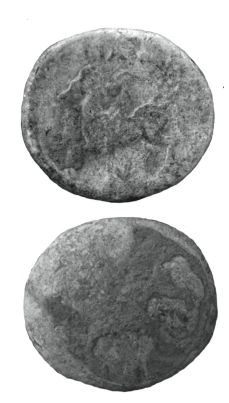

